DOI: 10.2478/RAE-2019-0035 Review of Artistic Education no. 18 2019 309-323

\title{
5. THE CHALLENGES OF IMPLEMENTING A FORMATIVE AND INNOVATIVE PRAXEOLOGY IN ARTISTIC EDUCATION
}

\author{
Tatiana Bularga ${ }^{312}$
}

\begin{abstract}
In efforts to design the implementation process of innovative artistic praxeology we emerged from the assumption that TDA (teacher's didactic action) and PAA (pupil artistic action) become fundamental values of the integration of theory and praxeology in perspective of an effective education, provided that they be widely used both horizontally and vertically, according to the pentagonal model consisting of principles: proactivity, artistic introopening, creation/creativity, of success, re-conceptualizing and instrumented in modern theoretical and methodological perspectives. Modern education, especially the artistic one, has a stringent need of an innovative praxeology, which, unlike the receptive praxeology, does not take over the rough theoretical and methodological approaches, but obliges the practitioner to gather from the available sources only the ideas of perceived essences, so that later to come before pupils with new actional options. Such a praxeology becomes more than just a practical act, because it puts the teacher in the role of interim manager function between theory and practice.

Key words: artistic education, efficiency, innovative and artistic praxeology, artistic action of teacher, artistic action of pupil/student, proactive behavior, success of personality, actional options, implementation process
\end{abstract}

\section{Introduction}

School is for the child a specific social world, where he/she enters into relationships with his/her peers, with the teacher, with the disciplines. He/she has many and various questions, to which he/she awaits the enigmatic answers. Obtaining the awaited answers multiplies his/her effort of knowing, of always being in a quest and of discovering phenomena not known until that moment. If the need to act independently and creatively is opportune for the school disciplines, then this need is much more felt in the disciplines with an artistic content (music, painting, choreography, etc.).

In order to continuously stimulate the student's effort so that he/she may pro-actively manifest himself/herself, independently and successfully, it is not enough to have a receptive pedagogical praxeology, which is reduced to the fact that the docile teacher aims at translating into practice the theoretical and methodical undertakings exposed in the speciality literature, guides, curricula, etc. Contemporary education, especially the artistic one, has a stringent need for a innovative praxeology, which, unlike receptive praxeology, does not take raw theoretical-methodical undertakings, but forces the practitioner to reap from the

\footnotetext{
312 Associate Professor PhD., „Alecu Russo” State University from Bălţi, Republic of Moldavia, email: tatianabularga@rambler.ru
} 
sources made available only the ideas of the essences perceived, so that he/she may subsequently come before the students with new action options. Such a praxeology becomes more a practical action, as it places the teacher in the role of manager with an intermediary function between theory and practice. In this state, the practitioner fully corresponds to praxeological strictness, which boil down to the specificity of projecting and logistically performing the artistic action.

The desideratum of the implementation of a formative-innovative praxeology in the national artistic education is not a whim of the moment nor a purely theoretical undertaking, but a vital, practical need, which aims at rallying all human resources in order to change both the integrative-professional vision of the teaching staff and their direct responsibility for the quality of the actions done day by day with the actors of the training process.

Ample investigations carried out in the field on the named subject confirm our assumptions previously formulated about the fact that:

a) practice, unlike theory, is a vivid, mobile process often with hostile tendencies regarding change;

b) the dynamics of a Postmodern pedagogy theory undeniably needs a functional innovative praxeology;

c) current educational technologies entail an organized system, where components can and must be applied in an integrated manner;

d) The correlation of the results of our research with the research results obtained for the time being prove that change strategies focused only on gifted/exceptionally gifted school students/students does not fully solve the problem, as they must offer equal chances to the entire sample of the training process.

The measures taken for this purpose do not exclude certain unforeseen risks, such as:

a) the low level of responsibility and attitude that certain manager and teacher can prove regarding the objectives advanced in the experimental research program and for the implementation of aimed praxeology;

b) the existence of omissions in ensuring the logistics necessary for the trainingeducational process in art schools;

c) the level of professional performances of the teaching staff, the low interest for the change actions in education, shall not initially ensure overall the awareness of the priorities of moving from traditional praxeology to the training-innovative one;

d) the practitioner's access to theoretical-methodical materials, curricula/textbooks and their assessment for the purpose of successfully achieving a qualitative education for the purpose of change.

Thus, the analysis of the predictable risks implies the need to change practitioners from the awareness of artistic education as a secondary phenomenon to a cultural primary one for the European society. In this context, 
efforts for the corroboration of university and pre-university factors were applied for the purpose of achieving the changes designed.

\section{Methodological landmarks}

Pedagogy in all ages needed and continues to need a consistent theory and a predictable, anticipative practice that would tread not on the heels of, but before social-economic processes. Such a practice, in our opinion, finds its appropriate response in the training-innovative praxeology. Such praxeology meets all the components necessary for a tenable education and educational system with concrete outcomes for goals pertinent for a Post-modern humanist framework.

When we focus on innovative praxeology we take into account the reformation of pedagogy seens as science and as a humanist practice, constituted as an open system, which means that its primary objective is to revise, to reconceptualize educational principles; through its constituent constructs, training (teaching, learning, cognition) and education (training, development, change), which also asserts itself as a managerial science, insisting on both its roles on a qualitative, efficient and progressive action.

For the purpose of instituting a dynamic relationship between the successful theoretical approaches and practical applications of the scientificepistemological undertakings, one needs an optimal co-operation between theoretical acquisitions and the innovations of educational praxis. The qualitative connections between praxeology and theory cannot cause by themselves the changes desired in the educational process. But educational practice and its study, praxeology, constitute for educational sciences not only one of the three knowledge resources in the pedagogical research but also a significant epistemological keystone capable of contributing to the solution of the problems of pedagogy, especially in the optimization of the educational theory-practice relation.

We can observe such a connection and efficient co-operation between theory and practice both on the horizontal (applicative-active receptivity of practitioners to scientific undertakings and performances, on the one hand, and the systemic and continuous capitalization of practitioners' innovative experiences, on the other hand), and on the vertical, which means that the innovative praxeologist takes from theoretical projections not everything in detail, but only essential ideas in order to apply them independently, these being accompanied by another 2-3 options of the actor in the change process by practical innovation.

If we refer to the field of training personality through art, we notice that the practice of this educational course of action does not meet by far the technological demand specific to reception-understanding-creation of works of art processes. In this educational field, the undertaking for the optimization of the theory-practice report obtains instructive-formative and additional artistic development valencies, due to the principles of creation-recreation-reception of 
artistic products, which stipulates that the work of art exists as such only in the process of interpreting-visualizing-auditioning it - process which contains the mental action of the creation author, conventionally considered a theoretical one, with the reception action and, at the same time, being considered a practical one. The artistic reception process within instructive-formative actions is identified with the educational action itself. In this process, a significant weight is held by the participative state of the school student/student in the designing, carrying out and assessment/self-assessment action (by prescribing individual behavioural maps, anticipating practical actions, varying operations, carrying out tasks by choosing the optimal solution variants) and of the professional competence dynamics of the teaching staff to gradually execute the design (theoretical) and action (practice) process, by identifying educational contents and value actions, diagnosing individual resources, planning, forming hypotheses, sequential and final assessment.

The study of the practice of artistic education in the Republic of Moldova proves to us quite persuasively that there is a significant discrepancy between artistic theory and praxeology, a fact that negatively influences the management of implementing an innovative praxeology, meaning of training through innovation. The following are identified as efficiency criteria:

1. methodological (planned and executed by taking into consideration the application of technologies and efficiency strategies);

2. psychological (by taking into account mental factors, meaning the internal content of personality);

3. physiologic (school student/student-subject/object of education is a being gifted with mental/spiritual capacities, but also with physical capacities, which entails the promotion of a binomial educational policy, with an efficient connection of both forms of existence);

4. pedagogic (the usage of modern principles and technologies for an efficient management with the educational-formative process);

5. aesthetic (all cognitive-formative steps shall be executed based on classical and contemporary knowledge);

6. praxeological (teacher's didactic actions and school student's/student's artistic actions shall be instrumented and substantiated methodologically and executed with a high practical effect);

7. axiological (education is integrated and focused on values);

8. sociological (artistic education constitutes a microsystem of the society that the person is a part of and, respectively, that determines its formative purpose and ideal).

Implementation goals. In the series of actions regarding the implementation on stages of innovative praxeology in the national artistic education, a top place is intended for the actual implementation goals, which boil down to the following: 
- identifying stimuli-factors (internal and external) of the theory and practice integration process from the point of view of an efficient education;

- filing and examining strategies for the purpose of building of professional competences of the practitioner;

- checking the formative efficiency of praxeological models for the organization/advertising of the school student's/student's artistic action $(A A a E / S)$ in the context of three environments: educational, individual and artistic;

- validating theoretical-methodological execution of the pentagonal system, consisting of five unifying principles of the efficiency of the teacher's didactic action $(A D a P)$ and of the school student's/student's artistic action $(A A a E / S)$;

- creating and checking in the field the praxeological department of the pedagogic experiment and implementing the concept of efficiency in educational practice;

- formulating conclusions and practical recommendations, directed towards the efficiency of the school and university formative-artistic process.

Framework-objective. In close connection with the goals of implementing innovative-artistic praxeology the framework objectives of the targeted process are emphasized, which boil down to the following:

- compatibility of the national curricula and the textbooks in the artistic educational system, applied in the pre-university and university system;

- establishing the experimental sample of school students/students (experimental classes/groups, assessment classes/groups) and of the pedagogic framework of educators and experts;

- designing a methodology for the efficiency of pedagogic technologies used from the point of view of ensuring a qualitative education;

- designing efficient items for the initiation of school students/students in artistic actions;

- experimental assessment and the assessment of the efficiency of the process for the implementation of theoretical models of AA of school students/students under curricular and extracurricular conditions;

- designing of tests/questionnaires for the assessment of the efficiency of educational-formative actions.

Hypothesis. In the undertakings for the designing of the process for the implementation of innovative-artistic praxeology, we got out of the assumption that $A D a P$ (teacher's didactic action) and $A A a E / S$ (school student's/student's artistic action) become fundamental values of the process of integrating theory and praxeology from the point of view of an efficient education, provided that they shall be used at length both on the horizontal, and on the vertical, in line with the pentagonal model consisting of five principles: of pro-activity, of focusing on the value, of artistic intro-openness, of creation/creativity, of success, re-conceptualized and instrumented from modern theoretical and methodological points of view. 


\section{Artistic Action - Intermediary Link between Formative Theory and Practice}

General notions. Considering artistic action (AA) a fundamental component in the balancing of the theoretical and praxeological sphere, we condescend to identify the notion of action. Action is a word with a Latin origin with the meaning of "acsio", namely doing, taking action. In DEX (Explanatory Dictionary of Romanian Language), action is qualified as "the act of taking action, activity carried out for the purpose of achieving a goal." Starting from the essence of the named notion, we shall specify that the main meaning of it boils down to the phenomenon of taking action, but not randomly, but for the purpose of achieving a certain goal. Regarding the approach of the educational plan the question arises: "What is the dimension of the process of taking action?" In literature, action is treated as a practical act of an activity. However, there is also the opinion that action boils down not only to the practical sphere, but it also contains the sphere of design/planning, namely what takes place in mental (theoretical) terms. In other words, the deed of advancing the purpose of action, the intention of designing the path of the achievement, constitutes an action step. For this purpose, action exceeds the borders of an actual activity with its traditional components: purpose, reasons, operations, etc.

The school student's/student's artistic action constitutes an energized behavioural system (empowered/employed) by pedagogic stimuli (principles, methods, techniques), in order to continuously increase the effort, help the student register in the effort curve (I. Radu şi M. Ionescu). Pedagogic mastery, for this purpose, entails the directed stimulation of the school student's/student's attitudes towards instructive and social obligations, towards the degree of purpose introspection and motivational sphere. Systemic orientation of personality towards result, accompanied by the process of changing and innovating one's own values, must be continuously supported by personality factors: intelligence, initiative spirit, perseverance, autonomous will, increased artistic skills, creative imagination, emotional capability, responsibility.

For this experiment both aspects regarding AA theoretical sphere (of designing) and its practical sphere, namely the execution process, were taken into account. The emphasize given to a sphere or another of AA depends mainly on the school age. Thus, when working with students in lower classes, aspects regarding the practical sphere for the students' actions shall have a significant weight: audio-video, perception-interpretation, perception-game/choreography (vocal-choir interpretation, vocal-instrumental musicology, execution of dance moves, execution/creation of musical game, etc.). When working with teenager students, with common students with practical actions, theoretical actions shall have a particular weight: design/anticipation, making hypotheses, analysis, generalization, etc.

The Stimulus - Response/Behaviour relation in the AA context is especially lobbied for the purpose of obtaining a brief connection effect, against 
the tendency to vary various causes that often, in the context of education, we do not even take into account. The artistic message offers the person concrete multiple possibilities of varying his/her feelings. The ability to vary depends on the degree of manifesting pro-activity. A pro-active person creates from a simple feeling a range of new feelings and meanings, a succession of composite feelings, that he/she brings to a fundamental meaning and vice versa, while the reactive person tends towards a trivialisation, vulgarisation of meanings, rather opting for a range of meanings that belong to the ones learned. The effective power of a person in artistic fields and not only is that o operating with the freedom to between the stimulus ( $\mathrm{S}$ theoretical/practice) and the response ( $\mathrm{R}$ theoretical/practical) feelings or values, personal decisions or circumstances aspects requisite to the model of artistic pro-activity.

In the initial stage we especially intend to emphasize the steps of the AA efficiency, although tangentially we shall not miss the moment of emphasizing the role of one or another type of practical action (ADaP, AAaE/S) in increasing the quality of the educational/formative process. Here, the anticipated goals are modest in the theoretical sphere, as the main focus is placed on designing guidance technologies/techniques with the functioning processes of the elements of one action. Re-conceptualization of AMA is important, treated as an integrating phenomenon between theory and practice, between teacher and student, between design and execution, between stimulus-purpose $(\mathrm{S} / \mathrm{P})$ and stimulus-response-behaviour (S/R/B).

In all experimental stages 5 efficiency principles remain fundamental, methodologically re-conceptualized and instrumented from the point of view of a qualitative education:

- the principle of pro-activity ("to be" and "to know";

- the principle of value alignment ("to have the freedom to choose");

- the principle of artistic intro-openness ("to be open to the truth", the presence of the state of "openness towards the beautiful, towards the intimate");

- the principle of creation and creativity ("to be inventive", the presence of the state of "novelty redemption");

- the principle of personal success ("continuously aspiring towards change in a new capacity").

AaaE/S efficiency, having as theoretical foundations the principles mentioned, is studies from the point of view of III levels for the performance of the objectives of the implementation of innovative-artistic praxeology, which are based on the following levels of performance:

1. The theoretical level, which is brought upon in order to emphasize the opportunities and risks of the theoretical designing carried out throughout the artistic education;

2. The cognitive-proximate level leads us towards the carrying out of an activity of identifying and overlapping the content of textbooks, guides, methodical recommendations and other materials with a didactic function, on 
the one hand, and their connection to the content of theoretical undertakings, on the other hand;

3. The praxeological level, which starts by stressing the study of practical success both from the ones being trained and from the ones who guide the actual training process.

In its turn, each of the three above-mentioned levels connects its content to the scale of another 8 levels of artistic training, taking into account the following aspects:

1. of content;

2. of

5. of expectation;

attitude/motivation;

6. of performance;

3. of designing;

7. of assessment;

4. of moulding;

8. of approval/disapproval.

Determining the levels of artistic performance shall allow the focus of the implementation process on certain efficiency factors both of the school student's/student's artistic action and of the action of the teaching staff.

Conditions under which the artistic action is being carried out. The instructive-educational environment (MIE) lays stress on the regulatory undertakings for the qualitative carrying out of the teaching-learning-training process (curriculum, contents, methods, principles, objectives, strategies, concepts, textbooks, methodical guides, etc.) As concerns the nature of the mentioned environment, it would first and foremost be about stimulation in school students/students of the individual need for self-improvement, change, perfection. We approach these personality qualities not from the simple desire to emphasize preferences for a certain type of activity, but in favour of perfection as a style of existence, as a manner of being, of existing, of operating.

The individual environment (MI), unlike other environments, is quite a difficult environment, closed, as the object/subject of education is in the centre of its functioning - the school student/student with multiple and various particularities: mental (attention, thinking, will, imagination, affection, etc.), of personality (cognition, intelligence, attitudes, consciousness, empathy, etc.), of behaviour (reproductive/creative, pro-active/reactive, focused on values/nonvalues action, intro-opened/closed, located in success/unsuccess). Each person, in relation with the cultural environment, instructive-educational environment builds a space, a personal, individual intellectual environment. The intervention of new phenomena in the individual's space or environment, depending on the principles that guide the concrete person, on the content of individual maps (succession of action steps made in compliance with efficient/inefficient principles), on the behaviour carried out with a positive/negative nature - all these form that unique, novel personality style.

The artistic environment (MA) integrates the MIE and the MI which grants the teacher and the school student/student the chance to bond in a well-balanced manner, in order to contribute to effective outcomes. The artistic environment 
represents a sub-division of the hereditary and social environment with a claim for wholeness, as it constitutes the fundamental element of integrity. In other words, we can state that this environment constitutes an external layer and, at the same time, an internal incorporation into the structure of personality, forming this framework, inter-environment of manifestation, of self-achieving individual potentialities. The school student's/student's activism manifested by: critical thinking, integrated imagination, creative, emphatic and pro-active imagination constitutes the mediator, connection factor between the person's internal and external world.

All these three environments mentioned above have a theoretical and a practical significance. Therefore, pedagogic praxis cannot function in the absence and theoretical materials and vice versa, educational theory would be meaningless without the experimental basis carried out in the field; the acquisition of theoretical knowledge by the school student/student would be a useless collection without their conscious application into practice; innovative experiences would remain undeveloped and unconceptualized without a theoretical-methodological instrumentation so that they can become a path with a generalizing value significance and of a continuous progress of formative praxis.

Factors accompanying artistic action. Human action, partially, artistic action shall remain, as we have previously mentioned, the link between theory and practice, what forces us to emphasize the factors accompanying it from the point of view of an efficient praxeology. Amongst the factors accompanying artistic action we shall present:

- the interventions of the so-called positive factors, with a facilitating input and of the so-called factors, with a negative input, namely restraining. However, it is clear that on a case by case basis, these factors can influence both on a positive and negative range: the level of guidance with the elements of the process of artistic empathy of the school student/student; putting yourself in someone else's shoes, including, in artistic roles; the overlapping of one's own feelings with those of another; intimate openness through senses, artistic ideas, etc.

- AA efficiency motivation expressed by stimuli-reasons: imitation, exercise, execution in line with the model or externally prescribed "maps", remaking, change, dynamics, activism, freedom of decision, taking initiatives, selfguidance;

- motivational success, approached in terms of the principle of stimulation, organization and AAaE/S execution;

- value-reasons, conceptualized in artistic pro-activity and specified in the following manner:

a. the reason of "tacit influence" (W. G. Jordan) with the meaning of influencing the school student/student by the way of "being", of emitting what 
one is, of examining and understanding art, creating, interpreting it - all being stimulated by the factor-reason: "tacit influence";

b. the reason of "lasting satisfaction" (St. R. Covey) is a primary need in connection with artistic activity. This reason offers to the person resistance, strength of will in the repeated re-carrying out of the action;

c. the reason of artistic transfer on other areas of activity;

- artistic communication, carried out through language-specific means (e.g. musical) and other arts (intonation, poetic verbalization, mimic/pantomime, rhythmic/dance motions);

- external and internal stimulation;

- real and ideal result (effect);

- assessment and self-assessment of one's own behaviour and of other persons' behaviour;

Conditions for the organization of an artistic action. First and foremost, we shall start with the conditioning of artistic action, which can be:

\section{theoretical:}

- formulating the purpose-reason (what do I have to do?);

- identifying the conditions in which the AA is expected to be executed (where do I need to act);

- expectation of individual possibilities/readiness (what do I have at my disposal at the moment?);

- preventive calculation/assessment of the effect/earning obtained following the execution of AA (what do I get?);

\section{practical:}

- testing action means and techniques;

- choosing the optimal action options;

- availability to cooperate with the teacher and classmates;

- recognition and discrimination of current and final errors/failures;

- description and presentation before other people one's own feelings experience during the action;

- self-stimulation of prompt reactions;

- projecting an artistic behaviour;

- assessing the level of openness of other persons towards one's own behaviour;

- finding the level of influence on other person of one's own accepting behaviour.

In the organization cast of artistic action we can confront with the so-called predictable influences:

- in some cases behavioural-artistic openness of the school student/student towards spirit, towards the interior can be intentionally received with negative reactions by external factors;

- in the process of AA execution, restricting subjective factors are infiltrated: envy, cowardice, intentional inculpation, etc. 


\section{Projection, organization and practical execution of artistic action}

Such processes are carried out based on the laws governing the functioning of the pro-activity principle:

The following the stressed:

1) the AAaE/S objective:

- acting pro-actively, meaning acting with maximum will and initiative;

2) school student's/student's individual qualities, pro-actively transferable (*Questionnaires for variables: $\boldsymbol{a}, \boldsymbol{b}, \boldsymbol{c}, \boldsymbol{d}, \boldsymbol{e}$ see: annex, Table 1):

a) capitalization of individual potentialities entails school student's/student's guided action towards the complete performance of personal resources (consciousness, skills, abilities/skillfulness):

- consciousness in artistic action has the function of changing towards spiritual integration through the paradigms from the exterior to the interior, from the interior to the exterior and through personal/personality content;

- individual skills include variables that define resources for the successful execution of AA and reside in:

- the presence of emotional tone;

- optimal storage and preservation of artistic information;

- efficient mental processing of audio representations;

- flexibility of artistic thinking;

- critical attitude towards impressions suggested by art;

- practical abilities/skillfulness - inevitable resources in the context of actions with high outcomes. In the area of music, for instance, we specify the following reference abilities:

- differentiated and integrated perception of music;

- artistic verbalization/commenting and interpretation of musical content;

- improvisation/musicality/elementary musical composition.

b) self-adjustment of positive actions constitutes a behavioural variable in relation to the cause - effect phrase, due to the fact that any cause shall stimulate an effect provided that the effect shall be well-designed/planned. In the context of the qualitative change paradigm, the person is oriented towards cultivating a style of self-guidance of convergent actions, namely concentrating his/her efforts at the theoretical level (analysis, comparison, judgement, awareness) and at the practical level (rejection of influences and negative circumstances and accepting/embracing positive ones) .

Here we prioritize key-objectives:

- cultivating a positive thinking;

- starting in the AA designing from the end, as each art product is a finality, an action model executed in time, worth emulating.

c) reporting one's own initiatives to a performance ideal. An efficient person does not wait that solutions to situations and problems to be offered completely, but addresses them with his/her own initiatives and opportunities. Reporting personal initiatives to models, accepted educational/cultural ideals entails a 
critical and self-critical status, constituting a new stage in the evolution process of the change paradigm. For this purpose, the reference objective is opting for a qualitative action and result.

d) taking the responsibility. The person oriented towards qualitative results, usually wants, is prone to coming with a clever response (response+ability) or, in other words, it weighs in the level of personal resources (quantity and quality indices) and establishes the imprinting (moment) of adopting a decision in order to answer for his/her actions and not to blame the circumstances or not blame others for a personal failure. The reference objectives are as follows:

- choosing responses in relation to the situations;

- creating positive artistic circumstances;

- dominating circumstances and representations, feelings, personal experiences;

- taking responsibility for verbal messages and artistic evolutions;

e) cultivating a pro-active language. Through spoken or artistic language the transmission into the exterior of information matters takes places, including of affective-emotional states of the internal world. The word constitutes the main exponent of judgements, of our intentions. Cultivating a pro-active language in the educational sphere, means changing the mental paradigm towards yourself and others, especially when referring to process mediated by artistic values. For persons oriented towards result, personal/public success, the paradigm of proactive language shall have the following meanings: "I shall succeed in deeply understanding the musical message", "I wish to get to know more deeply the values of music", "I shall finish the musical-artistic action started".

\section{The dynamics of qualitative changes takes place:}

by means of perception/interpretation:

- musical-artistic content of creation (idea, theme, character);

- form and area of exhibition/execution (vocal, instrumental, dramatic, fairytale, lyrics, etc.)

- psychological burden (depth of feelings, suggestive power, empathic dimension);

- effect of organization change (re-organization, planning, changing behavioural attitudes, tendency towards success);

- independent action: taking experimental, self-educating initiatives.

Artistic action as a specific intro-openness. We understand the role of music in human existence not as any activity, which can be explained through reference verbs: to perceive, to interpret, to compose, to understand, to associate, to meditate, to feel, etc., but through the philosophic depth of music as principle + stimulus $(\mathrm{P}+\mathrm{S})$ of the response $(\mathrm{R})$ to questions coming from the interior/exterior. The insight into elements of musical language, moulding this musical material, very much specific, not to say enigmatic, constitutes the level of gradual openness of the school student/student towards the depth of the content. Explanation, deciphering (Hermeneutics) of musical-artistic depths is 
material to the level of artistic intro-openness, "general soul openness" (G. Bălan, 1975).

Consciousness is that factor that contributes to the building of state $+S$ (stimulus) with the meaning of insistently "requesting". "To request" is not randomly taken into account, but being aware of the necessary matters, meaning "knowing" what you need. Thus, the intro-openness of the I towards music does not mean artistic perception, conceived as an actual action, but a continuous search and in finding yourself in the musical phenomena perceived.

Amongst the principles that significantly contribute to the efficient orientation of organizational undertakings into musical pedagogy, we emphasize: the principle of artistic intro-openness and of value focus.

The focus on the principle of learning through action constitutes one of the factors of the openness towards music. Focusing the learning on the principle of action would be only half of the journey, namely that of the principle transcended by the conscious and active participation of the school students/students to learning processes. The second half of the dynamic journey, based on the principle of openness towards art/towards oneself/towards the world, boils down to the moulding of personality by a pro-active action, which becomes the basis of the efficiency of the educational process.

The study of the phenomenon of school students'students' openness towards was outlined around the following dependences:

- knowledge overloading affects the experience-behavioural preservation/maintenance share;

- together with the increase in the volume of the material, the preservation percentage decreases (I. Radu, 1999);

- mechanical learning equals forgetting the knowledge accumulated intuitively, non-logically;

- accumulation in exponential rhythms of information entails the continuous enriching and renewal of knowledge (I. Radu, 1999);

- comparing the feelings generated instantly with the ones of perception;

- retaining in the memory the issues intercepted;

- internalising the effects of musical sonorities;

- systematizing musical intonations;

- differentiating songs, harmonies, rhythms, tones of the musical creation;

- presenting characteristic intonations;

- styling artistic nature and content;

- identifying musical discourse content in terms of the real-metaphoric imaginary;

- original representation;

- breakdown of the whole in essential microstructures;

- synthetizing with a claim for globalization;

- focusing attention on values and orientation towards values; 
- self-stimulation through the capitalization of new representations and by extending the space of influence of the musical-artistic environment and the existing environment;

- experience through the emotional "sight" and "hearing" of the musical message as "yourself", as someone else:

- awareness of personal and other persons' successes and failures by studying the artistic message, conceived as a special environment-stimulus;

- spiritual-artistic experience, intimate universe and its improvement are permanently open to music and the reception-interpretation-musical creation (I. Gagim, 2004);

- proximate reflection;

- evocation of experience actions consonant to the actual musical message;

- suscitation of new ideas regarding the content of the musical creation perceived/interpreted;

- criticism of circumstances, unsatisfactory, non-valuable musical-artistic environment;

- approval or disapproval of AA factors;

- assessment and self-assessment;

- measurement of individual resources and estimation of the energy, strength necessary for a continuous effort activation.

\section{Conclusions}

Taking into consideration the previously presented conceptual undertakings, each school course, cycle of subject matters in the artistic education must emphasize the levels of teaching, namely: knowledge of phenomena, (What is this?), appropriation of new knowledge and skills, (What must I undertake?), execution through transfer of the things appropriated (How do I do it?), assessment/self-assessment of success variables (What is the efficiency of the action?).

In our statements, we stepped out of the reality that artistic activity differs much from other human activities through its ontological specificity, which requires to take into account the opportunities and challenges visible in the manifestation of the school student's/student's individual potential, action which is expressed through the transfer of theoretical prescriptions onto practical actions undeniably through the presence of emotional-affective reactions, through the experience of the logistic projects and maps of the action, namely not only by waiting certain stimuli from outside, but fortifying certain intentions and artistic decisions of the school student/student-subjects of education.

\section{References}

1. BABII, Vladimir, Eficienţa educaţiei muzical-artistice, Chişinău, Editura „Elena V.I.”, 2005. 
2. BABII, Vladimir, Teoria şi praxiologia educaţiei muzical-artistice, Chişinău, Editura "Elena V.I.", 2010.

3. BABII, Vladimir. The intelectual dimension of the musical-artistic performance. în Rewieu artistic, Iași, Publishing: "George Enescu" University of Arts Iaşi. ISSN = $2069-7554$. ISSN-L = $2069-7554$.

4. BABII, Vladimir; BULARGA, Tatiana. Praxiologia inovativ-artistică. Iași: Editura ARTES, 2015. ISBN 978-606-547-276-1.

5. BABII, Vladimir., BULARGA, T. Succesul artistic al elevilor din perspectiva devenirii personalităţii social activel Materialele Conferinţei ştiinţifice naţionale cu participare internaţională "Fundamente psihopedagogice ale prevenirii şi combaterii violenței în sistemul educaţional", 10 octombrie 2014, Univ. Ped. de Stat "Ion Creangă", Fac. Psihologie şi Psihopedagogie Specială, Catedra Psihologie, Chişinău, 2014, p. 214-224. ISBN 978-9975-11553-7. 37.015.3(082)=135.1=161.1 F 97.

6. BABII, Vladimir. Praxiologia educaţiei artisticel Educaţia artistică în contextul mediului social-cultural al sec. al XXI-lea, Bălți, 2014, p. 17-20. ISBN 978-99-75-4227-3-4

7. BABII, Vladimir., Vasile, V. Aptitudinile muzicale între realitate şi ideal/ Educaţ̧ia artistică în contextul mediului social-cultural al sec. al XXI-lea, Bălți, 2014, p. 13-17. ISBN 978-99-75-4227-3-4.

8. BABII, Vladimir. Dinamica gîndirii muzicale / În: Materialele Conferinței ştiințifice internaţionale «Ion Gagim şi universul muzicii». Academia de Științe a Moldovei. Editura Artes, Iaşi., p. 179-183. ISBN 978-606-547-192-4.

9. BABII, Vladimir., BULARGA, Tatiana. Dimensiunea educațională a creativității muzicale in cadrul euroregiunii Siret-Prut-Nistru/ Editia a-X-a "Dezvoltarea economico-sociala durabila a euroregiunilor si a zonelor transfrontaliere în cadrul forumului transfrontalier al euroregiunii Siret-PrutNistru", Bălţi, p. 21-22. ISBN 978-606-687-109-9.

10. BABII, Vladimir. Educaţia artistică: abordare praxiologică. Conf. şt. internaţională: Învăţămîntul universitar şi piaţa muncii: conexiuni şi perspective. Chişinău, USM, 21-22 noiembrie, 2014.

11. BABII, Vladimir. Eficienţa acţiunii muzical-artistice a elevului: studiu teoretico-praxiologic. Conf. şt. internaţională: Eficientizarea învăţămîntului vector al politicilor educaţionale moderne, Chişinău, IŞE, 11-12 decembrie, 2014.

12. BULARGA, Tatiana, BABII, Vladimir. The success of artistic education: integration approache. In: Review of artistic education. Artes Publishing House, Iași. ISSN=2069-7554 ISSN-L=2069-7554. Included in CEEOL, EBSCO, Index Copernicus, 2014, p. 250-259. 